\title{
Ecophysiological Studies of Eleusine indica (L.) Gaertn. and Sporobolus pyramidalis P. Beauv. at Ibadan, Nigeria
}

\author{
B.M. SHARMA
}

\section{Abstract}

Eleusine indica and Sporobolus pyramidalis are common grasses in the tropics, including Ibadan, Nigeria. The former is consldered a good fodder when young, but the latter has low grazing quality. The objective of this study was to describe some of the morphological characteristics of these 2 prominent species. S. pyramidalis is a taller grass having more roots per culm and a longer inflorescence. Seeds of the 2 grasses germinated between $20^{\circ} \mathrm{C}$ and $35^{\circ} \mathrm{C}$ and emergence declined with increasing depth until it was zero at and 4 $\mathrm{cm}$ for $\boldsymbol{E}$. indica and $S$. pyramidalis, respectively. S. pyramidalis had a higher rate of germination. The 2 species have stomata on both leaf surfaces, but the number is greater on the adaxial surface. Experiments indicate that $E$. indica is more tolerant and adaptable to biotic disturbances. The biomass contribution by $\boldsymbol{E}$. indica and $S$. pyramidalis is estimated at $1,100 \mathrm{~kg} / \mathrm{ha} 300 \mathrm{~kg} / \mathrm{ha}$, respectively.

A knowledge of the developmental physiology of grasses is of considerable importance in the management of grasslands. The present investigation of the tropical grasses Eleusine indica (L.) Gaertn. and Sporobolus pyramidalis $\mathbf{P}$. Beauv. is a contribution to our understanding of their ecology and will likely aid the agriculturist in managing these species. $E$. indica, commonly known as fowl-foot grass, has been described by Purseglove (1975) as a successful species of Africa and Asia and is now widely spread throughout the tropics of both hemispheres. It has been introduced into the United States where it is a weed common to many of the warmer states. In the tropics, it grows from sea level to about 1,800 $m$. The species is particularly common in waste places and along road sides and paths. It was considered a good fodder when Young and Bogdan (1977) further reported it as palatable to cattle in Fiji, Hawaii, South America, and other areas of the world. S. pyramidalis is another common grass in Nigeria (Stanfield 1970). It is a tufted perennial plant having low grazing quality and is considered unpalatable to livestock.

It has been observed that the population of $E$. indica is affected by grazing in preflowering condition. The spread of the plant depends mainly on seeds. Both species are adversely affected by repeated cutting. Mclllroy (1964) reported that $E$. indica thrives well in trampled areas and becomes dominant along cattle tracks and paths. Our observation is that both species are conspicuously absent under shade.

\section{Study Area}

The investigation was carried out at Ibadan $\left(7^{\circ} 22^{\prime} \mathrm{N}\right.$ latitude, $3^{\circ} 58^{\prime}$ E longitude) during $1979-80$, on an area of 1,032 ha where 4 sites were chosen. The sites were as follows:

Site I - levelled area

Site 11 - in the vicinity of a small lake

Site III - area with depression and shade

Site IV - comparatively elevated and sloping area.

The silt loam soil at these four sites ranged in $\mathrm{pH}$ from 7 to 8 ,

The author is a senior lecturer in botany at the University of Ibadan in Nigeria.

The author is grateful to Professor A.U. Patel, Department of Agricultural Extension Services, University of Ibadan, Nigeria, for his guidance in the statistical analysis of the data. Thanks are due to Mr. A.J. Afolayan for help in the collection of data. Manuscript received January 18, 1983. organic matter was $3.2 \%$, except at Site II where it was $6.8 \%$ and the water holding capacity averaged $35 \%$.

Climate at Ibadan is characterized by 2 distinct seasons: a humid, wet season occurring in March through October, and a dry season lasting from November through February. Sunshine hours ranged from 50 in September to 209 in February, 1979. Precipitation totaled $1,740 \mathrm{~mm}$ with $343 \mathrm{~mm}$ falling in August. The mean, daily minimum and maximum temperatures ranged from a low of $20^{\circ} \mathrm{C}$ in December to a high of $36^{\circ} \mathrm{C}$ in February.

\section{Materials and Methods}

Three plant specimens of $E$. indica and 3 of $S$. pyramidalis were carefully collected from each of the 4 sites for morphological characterization. Their plant associates were identified with the help of regional and local flora (Hutchinson and Dalziel 1931, 1963, 1972 and Stanfield 1970). The phytosociological investigations were carried out on 20 quadrats $(50 \times 100 \mathrm{~cm})$ at each site to determine frequency, density and cover. Importance Value Index (I.V.I.) was calculated for each specie by adding relative frequency, relative density, and relative cover values (Curtis and McIntosh 1951).

Seeds collected for germination studies were stored for 3 months and then sterlized with $0.1 \%$ mercuric chloride. Twenty seeds were geminated on filter paper placed in petridishes. Germination was tested at temperatures ranging from $10^{\circ} \mathrm{C}$ to $40^{\circ} \mathrm{C}$. Emergence was also evaluated under glasshouse conditions when seed was planted at 0 to $5 \mathrm{~cm}$ soil depths. All germination and emergence experiments were carried out in triplicate.

\section{Results and Discussion}

\section{Morphological Features}

Quantitative observations on the morphology of $E$. indica and $S$. pyramidalis are indicated in Table $1 . E$. indica acquired a height

Table 1. Morphological features of Eleusine indica and Sporobolus pyramidallis at Ibadan, Nigeria.

\begin{tabular}{lcc}
\hline \hline Parameters & E. indica & S. pyramidalis \\
\hline Height, cm & $30-62$ & $45-62$ \\
Number of leaves per culm & $4-5$ & $2.6-3.6$ \\
Number of spikes per culm & $4.2-5.6$ & $47-80$ \\
Number of seeds per spike & $58-76$ & \multicolumn{2}{c}{-} \\
Depth of longest root, cm & $8-17$ & $8-10$ \\
Number of roots per tiller & $9-11$ & $10-20$
\end{tabular}

range of 30 to $62 \mathrm{~cm}$ with maximum height occurring at Site II. The vigorous growth here was due to a plentiful and perpetual supply of water from the lake. Greatest rooting depth and greatest number of seeds per culm were found at Site IV. Plants at Site III were the shortest, suggesting that they do poorly in shade.

$S$. pyramidalis is generally a taller grass, has more roots per tiller and a longer inflorescence in comparison to the former species. Both species have a shallow fibrous root system with a large 
number of roots. Adventitious roots develop from the lower nodes under adverse conditions. Root hairs are long and readily visible. Though the contribution of roots to the biomass is less than shoots, they add to the organic matter of soil.

\section{Phytosociological Relations}

The Importance Value Index (IVI) for 10 of the 23 species encountered in 20 quadrats at each of the 4 sites is given in Table 2.

Table 2. Importance Value Index of Weed Species at four sites in Ibadan, Nigeria.

\begin{tabular}{lrrrr}
\hline \hline & \multicolumn{4}{c}{ Importance Value Index } \\
\cline { 2 - 5 } Name of species & 1 & II & III & IV \\
\hline Axonopus compressus & 25 & 24 & 28 & 15 \\
Borreria ocymoides & 19 & 21 & - & 24 \\
Cynodon dactylon & 3 & 29 & - & 1 \\
Desmodium triflorum & 41 & 14 & - & 11 \\
Eleusine indica & 58 & 74 & 79 & 67 \\
Eragrostis tenella & 24 & 9 & - & 4 \\
Oldenlandia corymbosa & 9 & 3 & 24 & 18 \\
Setaria barbata & 11 & 31 & 12 & 14 \\
Sporobolus pyramidalis & 57 & 70 & 86 & 80 \\
Synedrella nodiflora & 12 & 23 & 26 & 16 \\
\hline
\end{tabular}

The highest dominant species were $E$. indica at Site I and II. and $S$. pyramidalis at Site III and IV. The codominant species with $E$. indica on Sites I and II were $S$. pyramidalis and Desmodium triflorum, $S$. pyramidalis and Setaria barbata, respectively. The codominant species with $S$. pyramidalis on Sites III and IV were $E$. indica and Axonopus compressus, E. indica and Borreria ocymoides, respectively.

Species having an IVI greater than 20 at one or more sites were $A$. compressus, $B$. ocymoides, Cynodon dactylon, D. triflorum, Eragrostis tenella, E. indica, Oldenlandia corymbosa, $S$. pyramidalis Synedrella nodiflora, and S. barbata. Based on IVI, the communities at Sites I to IV are as follows:

Eleusine-Sporobolus-Desmodium Community

Eleusine-Sporobolus-Setaria Community

Sporobolus-Eleusine-Axonopus Community

Sporobolus-Eleusine-Borreria Community

\section{Germination Studies}

Results of germination studies for the 2 species at different temperatures, soil depths, and environments are presented in Table 3. $E$. indica seeds germinated between $20^{\circ} \mathrm{C}$ and $35^{\circ} \mathrm{C}$ with optimum temperature being $25^{\circ} \mathrm{C}$. $S$. pyramidalis seeds germinated between $15^{\circ} \mathrm{C}$ and $35^{\circ} \mathrm{C}$. Optimum temperature was $25^{\circ} \mathrm{C}$. $S$. pyramidalis had a higher rate of germination.

Optimum germination and emergence occurred at the surface and declined with depth. For $E$. indica there was no germination below $2 \mathrm{~cm}$ and none below $3 \mathrm{~cm}$ for $S$. pyramidalis. The fact that these grasses have very small seeds, $1 \mathrm{mg}$ and $0.1 \mathrm{mg}$, respectively, may explain the higher rates of emergence near the surface than when buried in the soil where food reserves are inadequate to allow extension of the plumule through the overlying soil.

The trend of germination of two species in different environments again indicates that $S$. pyramidalis does well in all environments while $E$. indica does not germinate in continuous light.

\section{Studies on Transpiration}

Stomata were elliptically shaped pores ranging from 15.0 to 17.5 $n m$ by 22.5 to $25.0 \mathrm{~nm}$ in $E$. indica while 12.5 to $15.0 \mathrm{~nm}$ by $25.0 \mathrm{~nm}$ in $S$. pyramidalis. The 2 species are amphistomatous, i.e., having stomates on upper and under leaf surface, but the number of stomata is greater on the adaxial surface on the leaf. The stomatal density was $710 / \mathrm{mm}^{2}$ and $490 / \mathrm{mm}^{2}$ on the adaxial and abaxial surfaces respectively for $E$. indica and $540 / \mathrm{mm}^{2}$ and $390 / \mathrm{mm}^{2}$, respectively, for $S$. pyramidalis.
Table 3. Germination (\%) for Eleustne indica and Sporobolus pyramidalis at different temperatures, soil depths, and environments.

\begin{tabular}{lcc}
\hline \hline $\begin{array}{c}\text { Conditions of } \\
\text { germination }\end{array}$ & E. indica & S. pyramidalis \\
\hline Temperature & 0 & 0 \\
$10^{\circ} \mathrm{C}$ & 0 & 5 \\
$15^{\circ} \mathrm{C}$ & 10 & 20 \\
$20^{\circ} \mathrm{C}$ & 40 & 60 \\
$25^{\circ} \mathrm{C}$ & 15 & 40 \\
$30^{\circ} \mathrm{C}$ & 5 & 10 \\
$35^{\circ} \mathrm{C}$ & 0 & 0 \\
$40^{\circ} \mathrm{C}$ & & \\
& 45 & 75 \\
Soil Depth (cm) & 15 & 35 \\
Surface & 10 & 20 \\
1 & 0 & 5 \\
2 & 0 & 0 \\
3 & 0 & 0 \\
4 & & \\
5 & 0 & 5 \\
Environment & 15 & 15 \\
Continuous light & 30 & 65 \\
Dark & & \\
Glass house & & \\
\hline
\end{tabular}

Transpiration rate measured as weight loss per day per pot was $7.8 \mathrm{~mm} /$ day for $E$. indica, which was higher than the $5.2 \mathrm{~mm} /$ day measured for $S$. pyramidalis. This may result from the higher stomatal frequency and wider stomatal aperture in E. indica. Also, anatomical observation revealed a thinner cuticle for $E$. indica thereby allowing more cuticular transpiration. These evapotranspiration values were determined on potted plants and, therefore, may not reflect what actually happens under field conditions.

\section{Biomass Studies}

At the four-leaf stage, the shoot to root mass was $0.9 / 0.08 \mathrm{~g}$ for $E$. indica and $0.4 / 0.10 \mathrm{~g}$ for $S$. pyramidalis. Dry weight increases from the two-leaf stage on to maturity. At any stage of development, $E$. indica showed a relatively higher dry weight than $S$. pyramidalis. The average density of $E$. indica and $S$. pyramidalis calculated from 20 quadrats at each of the 4 sites was 5.4. The average total dry weight of root and shoot of individual plants under an ideal condition of daily watering was $5.3 \mathrm{~g}$ and $1.5 \mathrm{~g}$, respectively, as measured in another study. The estimated biomass for $E$. indica and $S$. pyramidalis, including both tops and roots, would be $1,100 \mathrm{~kg} / \mathrm{ha}$ and $300 \mathrm{~kg} / \mathrm{ha}$.

\section{Literature Cited}

Bogdan, A.V. 1977. Tropical pasture and fodder plants (grasses and legumes). Tropical Agricultural Series. Longman, London and New York.

Curtis, J.T., and R.P. McIntosh. 1951. An upland forest continuum in the prairie-forest border region of Wisconsin. Ecology 32:476-496.

Hutchinson, J., and J.M. Dalziel. 1931. Flora of west tropical Africa. Vol. I. Millbank, London.

Hutchinson, J., and J.M. Dalziel. 1963. Flora of west tropical Africa. Vol. II. Millbank, London.

Hutchinson, J., and J.M. Daltxiel. 1972. Flora of west tropical Africa. Vol. III. Millbank, London.

Mcllroy, R.J. 1964. An introduction to tropical grassland husbandry. Oxford Univ. Press, New York.

Purseglove, J.W. 1975. Tropical crops. Longman, London.

Stanfleld, D.P. 1970. The flora of Nigeria grasses. Ibadan Univ. Press. 